\title{
Factors Affecting E-Commerce Adoption and Their Impact on SMEs' Performance: A Case Study of Jabodetabek Region
}

\author{
Ratnaningsih Hidayati \\ Center for Trade Education and \\ Training \\ Ministry of Trade Republic of \\ Indonesia \\ Depok Indonesia \\ nanasoffan@gmail.com
}

\author{
Ririh Kusuma Permatasari \\ Center for Trade Education and \\ Training \\ Ministry of Trade Republic of \\ Indonesia \\ Depok Indonesia \\ ririhkusuma.pepi@gmail.com
}

\author{
Ashry Noviana Fajry \\ Center for Trade Education and \\ Training \\ Ministry of Trade Republic of \\ Indonesia \\ Depok Indonesia \\ ashrynov@gmail.com
}

\begin{abstract}
The development of information technology (IT) has disrupted the world business. E-commerce significantly increases effectiveness and efficiency in trade. This research analyzed organizational support, technology competence, and external environment as factors affecting e-commerce adoption by the Small Medium Enterprises. This study was conducted with the aim of identifying the impact of factors that influence e-commerce adoption on the performance of Small and Medium Enterprises in the Jabodetabek region. Quantitative approach with multiple regression analysis was applied as a tool to determine the impact of internal and external factors regarding e-commerce adoption to the SMEs performance. The results showed that the variables of organizational support, technology competence, and external environment, simultaneously affect the performance improvement on eCommerce adoption by SMEs in Jabodetabek region.
\end{abstract}

Keywords-organizational support, technology competence, external environment, e-commerce, performance improvement, SMEs

\section{INTRODUCTION}

The existence of small and medium enterprises (SMEs) is increasingly acknowledged in Indonesia when the monetary crisis occurred in 1997. It turns out that the SME sector is able to survive and contribute to the economic growth of our country. Therefore, after the crisis, the government's attention to the potential economic power of SMEs was increasingly enhanced.

The advance and development of information technology has now changed the map and ways of doing business. The increasing intensity of internet usage simultaneously accelerates the process of information exchange. OECD (1993) states that the adoption of information technology by SMEs is still very low compared to large companies. According to research results from Ihwana (2012) in Febriantoro (2018) found that only around 75 thousand of the 55, 2 million or equivalent to $0,0013 \%$ of MSMEs in Indonesia have used the internet to market their products.

The results of the APJII survey in 2018 show that Indonesia's internet penetration at the beginning of 2018 is only $50 \%$. Furthermore, it was explained that as many as $47 \%$ of Indonesian internet users access via cellphone. Of the total cell phone users, $31 \%$ buy goods/services online. This can be interpreted that e-commerce market opportunity in Indonesia is still wide open. E-commerce is an effective tool to promote business, increase sales and capture many customers without having to be limited by the location and time of the transaction.

Currently, e-commerce is become an important tool in business practice. SMEs as a potential economic power shall be able to utilize e-commerce to improve the performance of their companies. This study aims to determine to which extent the factors that influence e-commerce adoption in SMEs, namely organizational support, technological competence and the external environment will affect their performance.

This research analyzed organizational support, technology competence, and external environment as factors affecting e-commerce adoption by the Small Medium Enterprises. A set of questions was developed in order to explain the impact factors adopting e-commerce to SMEs performance within the Jabodetabek Area. They are :

1) Does Organizational support on e-commerce adoption has positive and significant influence to the performance of Small and Medium Enterprises in the Jabodetabek region.

2) Does Technology competence on e-commerce adoption has positive and significant influence to the performance of Small and Medium Enterprises in the Jabodetabek region.

3) Does External environment on e-commerce adoption has positive and significant influence to the performance of Small and Medium Enterprises in the Jabodetabek region.

4) Does Organizational support, technology competence, external environment on e-commerce adoption have simultaneously effect to the performance of Small and Medium Enterprises in the Jabodetabek region. 


\section{METHODOLOGY}

There are many researchers such as Shim et. al (2000) and Ihwana (2012) who had tried to define e-commerce and according to technological developments. The definition of e-commerce is also experiencing development not only limited to the process of buying and selling goods or services on the World Wide Web Internet (Shim, et al., 2000), but extends to the process of buying and selling or exchanging products, services and information through information networks including the internet (Ihwana, 2012 in Febriantoro, 2018). Even the definition of e-commerce has a broader scope of buying and selling activities through the internet, or conducting any transaction that involves the transfer of ownership or the right to use goods or services through a computer-mediated network (Ihwana, 2012 in Febriantoro, 2018).

The adoption of e-commerce, as one form of information technology, is considered the most suitable for SMEs because it allows businesses to conduct business activities in geographical areas with high speed, flexibility and economy. Another reason is the possibility of being open to entrepreneurs to do business that is more complex than before because of the convenience obtained from processing data through e-commerce adoption (Ningtyas, et al., 2015).

There are several reviews of literature that examine the impact of factors that influence e-commerce adoption of the performance of companies and SMEs. A number of research in different countries has examined factors affecting SMEs in adopting e-commerce. A research about e-commerce adoption by Egyptian SMEs by Rabie (2013) revealed that there are six main factors in influencing SMEs to adopt ecommerce, which are: the characteristics of decision makers, including level of education, level of position in the firm, support of management, and attitutude of the management; characteristics of organization, including organization activity, size of organization, asset had by organization, organization age, IT knowledge of the staff, and marketing capability of the organization; characteristics of innovation, including Perceived Relative Advantage ; e-readiness including Individual and organisation e-readiness); support of the government; and challenges in adopting e-commerce. In the same way, a research by Kabanda and Brown (2017) show that less of institutional readiness is the challenge faced by Tanzanian SMEs in adopting e-commerce within their organization.

A study about e-commerce adoption by SMEs in Indonesia has been conducted by Rahayu (2015). The study revealed that factors that influence SMEs in Indonesia in adopting e-commerce are perceived benefits, technology readiness, owners' innovativeness, owners' IT experience and owners' IT ability and individual factors .

According to previous research, organizational support is a crucial factors in adopting e-commerce as a business practice. Chewelos, et al. (2001) stated that organizational readiness significantly influences technology adoption. Grandon \& Pearson (2003) and Yulimar (2006) in their study found that organizational readiness is significantly proven as a determinant of e-commerce adoption.

As the leader of the company, SMEs owner have a profound role in supporting the organization in adopting e- commerce. Blake, 1994 in Ruppel \& Howard (1998) found that commitment from the highest management is very important to support cultural changes needed in information technology. Furthermore, Individual factor is a determining factor for e-commerce adoption in SMEs in developing countries. Business owners who have experience and capabilities related to information technology well the functions and benefits of e-commerce adoption will accelerate the e-commerce adoption process itself.(Rahayu \& Day, 2015)

Harrison \& Samson 1997 in Ningtyas (2015) indicated that Adoption of technology is directly related to the company's competitive advantage and plays an important role in improving company performance. Moreover, Low cost of technology will accelerate the e-commerce adoption process (Premkumar \&Robert, 1999 in Rahayu \& Day, 2015)

Sarosa \& Zowghi (2003) mention that competitors are one of the important external factors that are considered by companies in adopting information technology (IT). Thus, according to Yulimar (2006) External push has an influence on e-commerce adoption

This study analyzed impact of factors determining ecommerce adoption by SMEs to their performance by using multiple linear regression analysis method.

Respondents in this study are Small Medium Enterprise Entrepreneurs who have been educated and trained at the Center for Trade Education and Training (CTET). Survey conducted on July 2019. A Questionnaire was distributed to a random sample consisting of 40 respondents. The question in the questionnaire are both open and close type questions, measuring the attitude of the respondents using the Likert Scale 1-5 from strongly disagree to strongly agree.

Respondents are randomly selected from the CTET database with various backgrounds. Some information regarding to their characteristics retrieved in this study are the gender, company establishment and business sectors.

Based on the literature and research conducted by Hanum \& Sinarasri (2017) there are several factors affecting e-commerce adoption by Small Medium Enterprises. Those factors are technology, organizational, environment and individual. In this study, we will model the impact of factors affecting e-commerce adoption to the SMEs performance. The statistical model is modified from those discussed in Hanum and Sinarasri (2017). Previous research was constructing the statistical model for factors adopting ecommerce by SMEs and the second step is to relate the ecommerce adoption with the SMEs performance. Meanwhile in this research we directly use the three independent variables to determine their impact on SMEs performance. The statistical model constructed as follows:

$$
\mathrm{Y}=\mathrm{a}+\mathrm{b} 1 \mathrm{Os}+\mathrm{b} 2 \mathrm{Tc}+\mathrm{b} 3 \mathrm{Ei}+\mathrm{e}
$$

Where:

$\mathrm{Y}=$ Performance of the SMEs

Os = Organizational support in e-commerce adoption

$\mathrm{Tc}=$ Technological competency in e-commerce adoption

$\mathrm{Ei}=$ External environment in e-commerce adoption

b1, b2, b3 = regression coefficient

$\mathrm{e}=$ error 
Hypotheses for this study are:

H1: Organizational support on e-commerce adoption has positive and significant influence to the performance of Small and Medium Enterprises in the Jabodetabek region.

H2: Technology competence on e-commerce adoption has positive and significant influence to the performance of Small and Medium Enterprises in the Jabodetabek region.

H3: External environment on e-commerce adoption has positive and significant influence to the performance of Small and Medium Enterprises in the Jabodetabek region.

H4: Organizational support, technology competence, external environment on e-commerce adoption have simultaneously effect to the performance of Small and Medium Enterprises in the Jabodetabek region.

This study utilized questionnaire as a primary data source. Respondents are Small Medium Enterprises entrepreneurs who has been trained and educated at the Center for Trade Education and Training Ministry of Trade.

\section{RESULTS AND DISCUSSIONS}

\section{A. SMEs Backgrounf Information}

Before going into detail on the results of the study on Factors affecting e-commerce adoption and their impact on SMEs performance, this part will present an overview of some background information of the SMEs respondent. To obtain the data, this study conducted an online survey and among the sample respondents, result was obtained from 31 respondents.

TABLE I. RESPONDENT'S GENDER

\begin{tabular}{|l|c|c|}
\hline Gender & Number & Percentage (\%) \\
\hline Male & 9 & 29.03 \\
\hline Female & 22 & 70.97 \\
\hline Total & 31 & 100 \\
\hline
\end{tabular}

Table II shows that respondents are more likely a female-owned enterprises. Female respondents are dominating the survey's result. The composition of the sample's gender is $70.97 \%$ female and $29.03 \%$ male.

TABLE II. ADOPTION OF E-COMMERCE

\begin{tabular}{|l|c|c|}
\hline $\begin{array}{l}\text { e-commerce } \\
\text { adoption }\end{array}$ & Number & Percentage (\%) \\
\hline Yes & 26 & 83.87 \\
\hline No & 5 & 16.13 \\
\hline Total & 31 & 100 \\
\hline
\end{tabular}

Out of 31 respondents, 26 SMEs owners have adopted ecommerce as their business practice. This number indicates that e-commerce is a common practice for the sample respondents in doing their business.
TABLE III. BUSINESS SECTOR

\begin{tabular}{|l|c|c|}
\hline Business sector & Number & Percentage (\%) \\
\hline Fashion & 3 & 9.70 \\
\hline Culinary & 12 & 38.70 \\
\hline General trading & 4 & 12.90 \\
\hline Others & 12 & 38.70 \\
\hline Total & 31 & 100 \\
\hline
\end{tabular}

Table III shows that most of the respondents in the sample are in the other sector such as handcraft production and services. This business sector characteristic suit the ecommerce system.

\section{B. Factors affecting e-commerce adoption and their impact on SMEs performance}

Analysis of the data with a multiple regression analysis shows that the value of $\mathrm{R}^{2}$ is 0.6136 . This can be interpreted that $61.36 \%$ of the relation of the dependent variable (Y) which is SMEs' performance can be explained by the independent variables (organizational support in ecommerce adoption, technological competency in ecommerce adoption and external environment in ecommerce adoption)

TABLE IV. RESUlt OF MULTIPLE REgRESSION ANALYSIS

\begin{tabular}{cr}
\hline \multicolumn{2}{c}{ Regression Statistics } \\
\hline Multiple R & 0.7833 \\
R Square & 0.6136 \\
Adjusted R Square & 0.5707 \\
Standard Error & 1.5168 \\
Observations & 31 \\
\hline
\end{tabular}

Each hypothesis was tested with the F and t-test. F-test conducted to see the overall significance of the research model. Table $\mathrm{V}$ shows the result of F-test and t-test using Analysis of Variance (ANOVA).

TABLE V. RESUlT OF ANOVA

\begin{tabular}{|c|c|c|c|c|c|c|c|c|}
\hline & $d f$ & SS & $M S$ & $F$ & $\begin{array}{l}\text { Signific } \\
\text { ance F } \\
\end{array}$ & & & \\
\hline Regression & 3 & 98.6542 & 32.8847 & 14.2931 & 0.0000 & & & \\
\hline Residual & 27 & 62.1200 & 2.3007 & & & & & \\
\hline \multirow[t]{2}{*}{ Total } & 30 & 160.7742 & & & & & & \\
\hline & $\begin{array}{c}\text { Coeffic } \\
\text { ients }\end{array}$ & $\begin{array}{c}\text { Standard } \\
\text { Error }\end{array}$ & $t$ Stat & $P$-value & $\begin{array}{c}\text { Lower } \\
95 \%\end{array}$ & $\begin{array}{c}\text { Upper } \\
95 \%\end{array}$ & $\begin{array}{l}\text { Lower } \\
95.0 \%\end{array}$ & $\begin{array}{l}\text { Upper } \\
95.0 \%\end{array}$ \\
\hline Intercept & 0.2826 & 1.9872 & 0.1422 & 0.8880 & -3.7947 & 4.3599 & -3.7947 & 4.3599 \\
\hline Os & 0.6104 & 0.2318 & 2.6332 & 0.0138 & 0.1348 & 1.0860 & 0.1348 & 1.0860 \\
\hline $\mathrm{Tc}$ & 0.0706 & 0.1724 & 0.4095 & 0.6854 & -0.2832 & 0.4244 & -0.2832 & 0.4244 \\
\hline $\mathrm{Ei}$ & 0.1817 & 0.1640 & 1.1080 & 0.2777 & -0.1548 & 0.5183 & -0.1548 & 0.5183 \\
\hline
\end{tabular}

Sources: primary data, processed

Based on the analysis result, the regression equation was formulated as follows:

$$
\mathrm{Y}=0.2826+0.6104 \mathrm{Os}+0.0706 \mathrm{Tc}+0.1817 \mathrm{Ei}+\mathrm{e}
$$


Where:

$\mathrm{Y}=$ Performance of the SMEs

Os = Organizational support in e-commerce adoption

$\mathrm{Tc}=$ Technological competency in e-commerce adoption

$\mathrm{Ei}=$ External environment in e-commerce adoption

b1, b2, b3 = regression coefficient

$\mathrm{e}=$ error

From ANOVA, the result of F-test shows 14.2931 (Ftest > Fstat). It can be interpreted all the independent variables (organizational support, technology competency, and external environment) together significantly affect the dependent variable. Therefore, we can conclude that the three factors simultaneously affecting performance of Small and Medium Enterprises performance.

Regression coefficients of three independent variables, that are positive and statistically significant, indicate there is a direct relationship between these factors and the level of performance of Small and Medium Enterprises. Data analysis for regression equation shows that the regression coefficients for organizational support factors are positive and statistically significant. This can be explained that organizational factor variables have a positive effect on the level of e-commerce adoption. Thornton and Marche (2003) in Selim (2008) suggested that factors in Management Industry Experience; Planning / Strategy; Capital; Record of Financial Control; Expansion of Growth; Inventory Management / Channels; Advertising / Marketing Strategy; Market Position; Target Market; Customer Service / Experience is a critical key factor in e-commerce adoption by companies. Thus, it can be understood that SMEs with high organizational support for e-commerce adoption will improve their performance significantly.

The second variable in the model is the technological competency factor. The results of data analysis shows that this variable is positive but not statistically significant. This can be inferred that technological competency in this case those competencies related to e-commerce literacy is not a determining factor in the performance of SMEs in ecommerce adoption. This might be owing to the fact that the SME entrepreneurs who are the object of the study are entrepreneurs who are domiciled in the Jabodetabek region who have a relatively better level of digital literacy compared to those domiciled in other regions.

According to the literature reviewed, external environmental factors is equally important factor of the ecommerce adoption by SMEs. The results showed that external environmental factors are positive but not statistically significant. This fact might be interpreted as the performance of SMEs is not influenced by the external environment on e-commerce adoption of the organization. This may be due to the lack of establishment of sufficient ecommerce ecosystem so that there is no relationship between mutual dependence on suppliers and/or customers.

\section{CONCLUSION}

This study discovered that some of the hypotheses are accepted and others are rejected according to the regression coefficient significant test. Final result of the analysis are:

1. Organizational support on e-commerce adoption has positive and significant influence to the performance of
Small and Medium Enterprises in the Jabodetabek region.

2. Technology competence on e-commerce adoption have positive but has no significant influence to the performance of Small and Medium Enterprises in the Jabodetabek region.

3. External environment on e-commerce adoption has positive but has no significant influence to the performance of Small and Medium Enterprises in the Jabodetabek region.

4. Organizational support, technology competence, external environment on e-commerce adoption have simultaneously affecting the performance of Small and Medium Enterprises in the Jabodetabek region.

\section{RECOMMENDATIONS}

Regarding on statistical results, therefore authors would try to give some recommendations for the next research or for government institution which handle SMEs, i.e.:

1. For the next research, it is suggested to define the type of e-commerce used by SMEs, and focus on SMEs that have adopted e-commerce more in a more complex form if the research area still located in Jabodetabek.

2. In terms of Organizational support on e-commerce adoption has positive and significant influence, author suggest SMEs should improve their organizational support such as financial support and company leader commitment to implement e-commerce for their best performance.

\section{REFERENCES}

[1] APJII. (2018). Profil Pengguna Internet Indonesia. Jakarta: APJII.

[2] Blake, M. (1994). Teleworking in the Nineties. A look at Current Views. Managing Information, 1, 24-26.

[3] Chwelos, P., I. Benbasat, and A.S. Dexter (2001). "Research Report: Empirical Test of an EDI Adoption Model" Information Systems Research, (12)3, pp. 304-321.

[4] Febriantoro, W. (2018). Kajian dan Strategi Pendukung Perkembangan E-commerce Bagi UMKM di Indonesia. Manajerial, Vol. 3 No.5 Juni 2018, p.184-207.

[5] Grandon, E.E \& Pearson, M.J. (2003). Perceived Strategic Value and Adoption of Electronic Commerce: An Empirical Study of Small and Medium Sized Businesses, Proceedings of the 36th Hawaii International Conference on System Sciences - 2003.

[6] Hanum, A.N. \& Sinarasri, A. (2017). Analisis Faktor-Faktor yang Mempengaruhi Adopsi E-Commerce dan Pengaruhnya Terhadap Kinerja UMKM (Studi Kasus UMKM di Wilayah Kota Semarang). Maksimum, Vol.1, No.1, September 2017.

[7] Harrison, N \& Samson, D. 1997. International Best Practice in the Adoption and Management of New Technology, Department Industry, Science and Tourism, Australia.

[8] Ihwana, e. a. (2012). Empirical Study of E-Commerce Implementation among SME in Indonesia. International Journal of Independent Research and Studies, Vol.1, No.1.

[9] Kabanda, S., \& Brown, I. (2017). External factors affecting ECommerce institutionalization in Tanzania : a test and validation of Small and Medium Enterprise claims. Information Technology and Development, 23(2005), 59-85.

[10] Marcati, A., Guido, G., \& Peluso, A.M. (2008). The role of SME entrepreneurs' innovativeness and personality in the adoption of innovations. Research Policy, 37(9), 1579-1590. 
[11] Nelson, M.L and Shaw, M.J. (2005). The Adoption and Diffusion of Inter organizational System Standards and Process Innovations. Working Paper of Standard Making: A Critical Research Frontier for Information Systems MISQ Special Issue Workshop.

[12] Ningtyas, P.K., Sunarko, B., and Jaryono. (2015). Analisis Faktor yang Mempengaruhi Adopsi E-commerce dan Pengaruhnya Terhadap Kinerja UKM. Performance - Vol.21 No.1 Maret 2015.

[13] OECD. (1993). Small and Medium-sized Enterprises: Technology and Competitiveness. Paris: Organization for Economic Cooperation and Development.

[14] Rabie, M. (2013). The adoption of e-commerce in SMEs : an empirical investigation in Egypt. University of Stirling.

[15] Rahayu, R., \& Day, J. (2015). Determinant Factors of Ecommerce Adoption by SMEs in Developing Countries: Evidence from Indonesia. Procedia - Social and Behavioral Sciences, 195, 142-150.

[16] Ruppel C.P and G.S. Howard (1998). Facilitating Innovation Adoption and Diffusion: The Case of Telework, Information Resources Management Journal, 11, 5-15.
[17] Sarosa S and Zowghi, D. (2003). Strategy for Adopting Information Technology for SMEs: Experience in Adopting Email within an Indonesian Furniture Company. Electronic Journal of Information Systems Evaluation Volume 6 Issue 2 (2003) 165-176

[18] Selim, Hassan M., "E-Commerce Adoption and Acceptance by Firms: Exploratory Study" (2008). CONF-IRM 2008 Proceedings. 23. http://aisel.aisnet.org/confirm2008/23.

[19] Shim, JK, Qureshi, A.A. Siegel, J.G \& Siegel, R.M. (2000). The International Handbook of E-commerce, Chicago, Verlag.

[20] Yulimar, Vidi A. (2006). Analisis Faktor-faktor Yang Mempengaruhi Pengapdosian Electronic Commerce dan Pengaruhnya Terhadap Kinerja Perusahaan (Studi Pada Perusahaan Kecil dan Menengah di Indonesia. 